\title{
DESIGN AND EVALUATION OF AN ENHANCED SOLAR DRYER USING HEAT STORAGE UNIT FOR TOMATOES DRYING
}

\author{
Ghoniem, E. Y.* and Gamea, G.R.**
}

\section{ABSTRACT}

Mixed-solar dryer with heat storage unit improve the process of solar drying Roma tomatoes. This paper presents a performance comparison between two mixed-mode solar dryers. The dryers were identically designed and constructed, however one of dryers utilized mobile and easily adjustable flat solar storage unit attached to the drying chamber during night hours to improve the drying rates after sundown(enhanced). The dryers were tested under both day and night hours. Solar insolation, Air temperature changes of ambient and drying chamber, as well as relative humidity were measured during the drying process. Rehydratation ratio, color and sensory properties were used as a parameter for the dried sample quality. Temperatures inside the dryer that utilized the heat storage unit were approximately $5{ }^{\circ} \mathrm{C}$ higher than those in the normal dryer during night hours. The enhanced dryer overall showed a considerable increase in drying rate with a 33.3 and $36 \%$ decrease in total drying time for tomatoes quarters and discs respectively as compared to the normal dryer to reach the final moisture content. Newtonian equation fitted very well the experimental data and it is possible to accurately simulate the thin layer drying behavior of tomatoes drying by enhanced dryer. Two well-defined falling rate periods and a very short constant rate period were observed. Drying constant $(k)$ was greatly affected by drying air temperature and shape of tomatoes. Drying of tomatoes discs and quarters by enhanced dryer revealed good color, taste and appearance, meanwhile tomatoes halves gave unacceptable color. So, drying of halves is generally not recommended

Heat storage unit permits drying to continue even after sunset or when the environmental conditions such as rainfall and high relative humidity make it difficult for normal solar drying to take place.

\footnotetext{
*Professor of Agricultural Engineering, Higher institute of Agricultural cooperative , Egypt

**Associate Professor, Department of Agricultural Engineering, Faculty of Agriculture, Minoufiya University, Egypt
} 


\section{INTRODUCTION}

olar energy is a very large, inexhaustible source of energy. The N power from the sun intercepted by the earth is approximately $1.8 \times$ $10^{11} \mathrm{Mw}$ which is many thousands of times larger than the present consumption rate of all commercial energy sources on earth. Thus, in principle, solar energy could supply all the present and future energy needs of the world on a continuing basis. This makes it one of the most promising of the nonconventional energy sources. At the present time, solar energy is more attractive than ever as alternative energy resource which can provide heating, cooling and hot water at economically competitive costs and without environmental hazard. Because of the desirable environmental and safety aspects of solar energy, it is advisable to replace of nuclear or fossil energy even when its costs are slightly higher. However, there is a problem in using solar energy which can only be collected during daylight hours and sunny days. Thus, some provision must be made for storage to accommodate night time and cloudy-days demand. But all these disadvantages are outweighed by the twin benefit of the universality of the source and long term economy of operating a solar energy system. On the other hand, food dehydration is still the most widely used food processing technology in the world. It is extremely important method of food preservation in both developed and developing countries and there have been many recent new developments. Furthermore, dried foods are more concentrated than any other preserved form of foodstuffs. It is less costly to produce, there is a minimum of labor required, processing equipment is rather simple and inexpensive, dried food storage requirements are at a minimum and distribution costs reduced. Most solar dryer designs fall into three main types: direct, indirect and mixed-mode. In a direct solar dryer, the product absorbs solar energy that enters through a transparent cover. Direct solar radiation dries the product while the drying chamber protects the product from environmental elements. Indirect dryers have a separate compartment called the collector, in which the air from the outside passes through and is heated before entering the drying chamber containing the produce. The hot air flow provides the necessary heat to help evaporate moisture from the product as well as carry the evaporated moisture out of the dryer. A 
mixed-mode dryer combines the features of the direct mode and indirect mode dryers. The product is dried concurrently by both direct radiation and by convection from the collector heating the entering air. The mixedmode dryer has been found to be the most effective in terms of the time it takes to dry the product (Simate, 2001).

The main goal of solar drying is to remove moisture from the fruit or vegetable to a level that will prevent microbial growth $(\leq 20 \%$ wet bulb in this study) while maintaining acceptable quality of the product. The drying rate of product is dependent upon the rate at which the moisture content is evaporated from the surface of the tomatoes and how quickly the moist air is removed from the area adjacent to the surface of the tomatoes (Joshi et al., 2004). The drying rate also depends on the rate of mass transfer of moisture from the interior of the product to the surface of the product. During drying, the product structural changes cause a reduction in moisture transport inside the product. The mixed-mode dryers are composed of three main parts. The solar collector where the air is heated by the radiation emitted by the solar absorber, the drying chamber where the product is exposed to the hot air from the collector and the direct radiation, and the outlet chimney which aides the exhaust of moist air while utilizing a buoyancy effect (Vlachos et al., 2002).

Tomatoes is widely grown in all the regions of the world with a tropical or Mediterranean climate for its immature pods. It grows best in hot weather (temperatures above $25^{\circ} \mathrm{C}$ ). The total production in 2011 was 8.1 million tons in Egypt.(CAPMS of A.R.E, 2011). Dincer and Dost (1996) reported that a solar system designer must seek answers to some basic questions about energy storage before proceeding with a project, such as: 'What types of storage are available?' 'How much storage is required?' 'How will the inclusion of storage affect the system performance, reliability and cost?' 'What storage systems or designs are available?. Ozturk and Bascetincelik (2003) reported that the solid materials were economically more attractive for high temperature heat storage than fluids and their volume requirements were nearly comparable. Direct contact between the solid storage medium and heat transfer fluid was vital to minimize the cost of heat exchange in a sensible heat storage system. The charging and discharging process of a 
thermal energy storage system was recommended to be analyzed in order to optimize the system efficiency.

The choice of storage medium is often influenced by the working fluid in a solar heating system. Thus, if air is the heat transfer fluid used in a solar system, then a rock bed thermal storage is an obvious choice (Duffie and Beckman, 2006). Johnson (1992) cited thick section of 20-30 cm are used when the sun shines directly on the material, and thinner larger- area sections of $10-15 \mathrm{~cm}$ are used when the sunlight is diffused within a space where storage, and release occurs from the same surface.

The objective of this study is to improve upon the existing methods of solar drying by using heat storage unit with a mixed-mode dryer to determine if there is an improvement in the drying performance of tomatoes. The heat storage unit in this study is separate from the dryer and therefore they may be moved to different locations and orientations around the dryer to maximize the amount of insolation striking the drying system. Two identical dryers were built, one dryer with heat storage panel and the other without heat storage (normal). The dryers were tested under both day and night hours.

\section{MATERIALS AND METHODS}

\section{Construction of the solar dryer with storage heat.}

A mixed-mode solar dryer and the storage unit were designed and manufactured at the Agricultural Systems Engineering Workshop, King Faisal University, Saudi Arabia. The whole system was installed at Agricultural Experimental station, King Faisal University and was oriented to have an unobstructed southern solar exposure. The drying system consisted of three main sections: The drying chamber (direct solar dryer), solar collector and solar storage unit as schematically depicted in Fig. 1. The drying chamber was constructed of plywood (1.0 $\mathrm{cm}$ thick.) with shelves which were arranged in a stepped pyramidal face to expose products in all trays to direct sunlight. The stepped pyramidal face provides two shelves for positioning the drying trays $(30 \times 60 \mathrm{~cm}$ each). The trays were made of $0.15 \mathrm{~cm}$ mesh stainless steel wire screen. The trays were removed or placed into the drying chamber through a hinged door one the back side. 

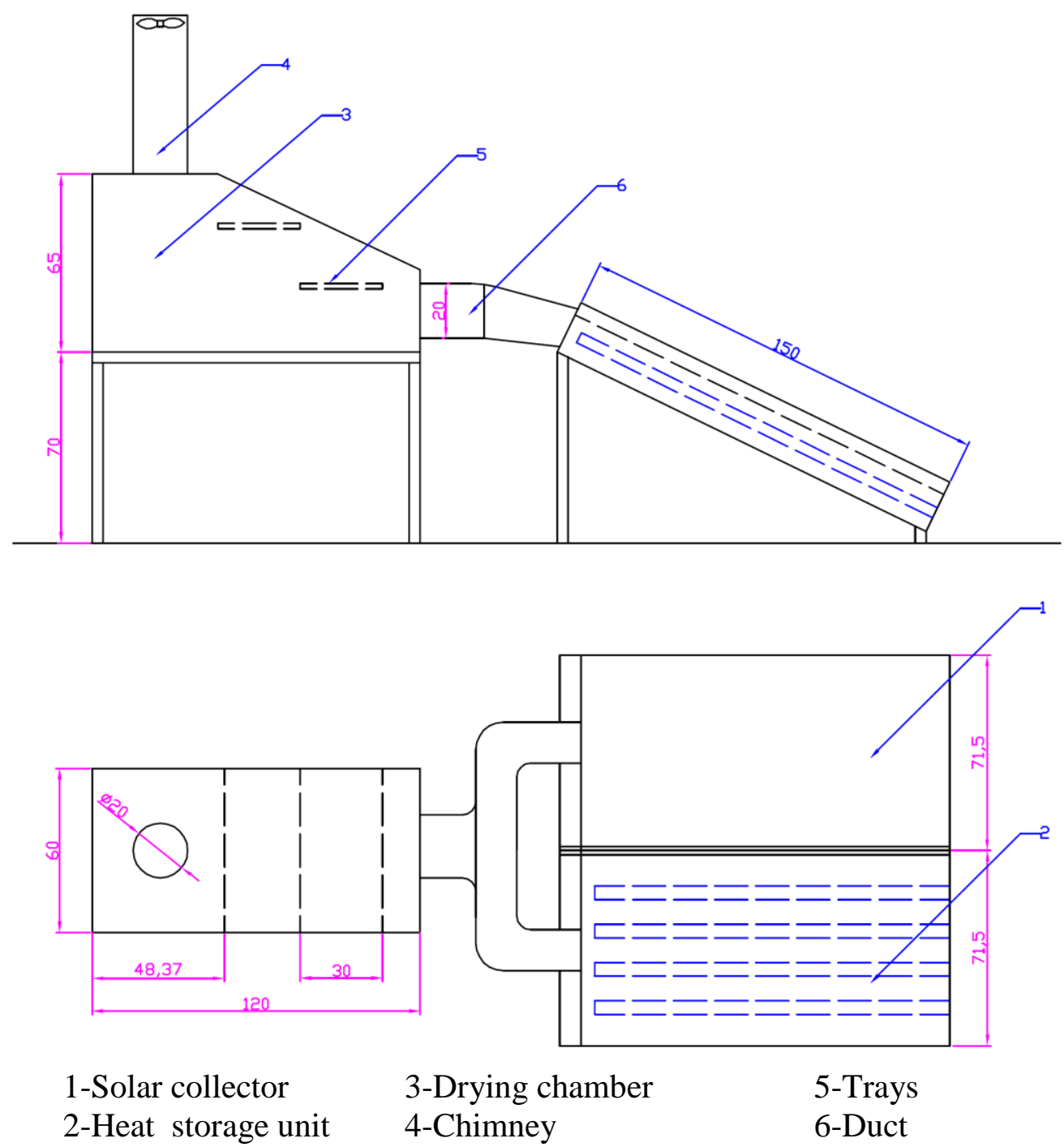

Fig. 1: Schematic diagram of experimental mixed solar dryer with heat storage unit

The dryer was mounted facing south with transparent cover tilted at angle of $25^{\circ} .56^{\prime}$ which was determined to be an optimum tilt angle for the specific location and time of the year (Abdellatif, 1985). A set of adjustable front legs on the cabinet to adjust the correct angle of inclination. To provide the draft needed to amplify the convective currents to displace the humid air in the cabinet, a cylindrical chimney made of $1.2 \mathrm{~mm}$ thick galvanized iron with an internal diameter $20 \mathrm{~cm}$ 
and $80 \mathrm{~cm}$ high was installed on top of the drying chamber. An extracting fan of $0.2 \mathrm{~m}$ external diameter (Sony, 20 wuc) 220-240 Volts (50 Hertz) was functional at the top of chimney. The air flow rate during experiments was adjusted at $0.075 \mathrm{~m}^{3} / \mathrm{sec}$ by adjusting the speed of the fan. (Mohamed et al., 2010 and Gamea et al., 2012).

The solar collector was made of wooden box having a gross dimensions of $1.5 \mathrm{~m}$ long, $0.70 \mathrm{~m}$ wide and $0.2 \mathrm{~m}$ deep. The absorber plate is formed of a corrugated iron sheet painted with matt black paint in order to absorber the maximum amount of the solar radiation. Air heated by solar collector was delivered to the drying chamber through a flexible insulated tube (15 cm diameter). The solar collector was oriented to face the south direction and tilted with an optimum tilt angle at the locality.

The Storage unit was made of having initial dimensions of $1.5 \mathrm{~m}$ long, $0.70 \mathrm{~m}$ wide and $0.2 \mathrm{~m}$ deep according to (Gamea et al., 2012). The walls and bottom were constructed of plywood (10 mm thickness) and a space between the glass cover and storage material was $2.5 \mathrm{~cm}$. four steel tubes were placed in the middle of the storage material as shown in figure (1) $(5.0 \mathrm{~cm}$ diameter and $145 \mathrm{~cm}$ length). Basalt granules were used as the heat storage material. The thermal properties of the basalt are given in table (1).

Table 1. Thermal properties of basalt . Somerton (1992), Dincer and

\begin{tabular}{ccccc}
\multicolumn{5}{c}{ Rosen (2010) } \\
\hline Material & $\begin{array}{c}\text { Density, } \\
(\rho) \\
\mathrm{kgm}^{-3}\end{array}$ & $\begin{array}{c}\text { Specific heat, } \\
(\mathrm{c}) \\
\mathrm{kJkg}^{-1} \mathrm{k}^{-1}\end{array}$ & $\begin{array}{c}\text { Thermal } \\
\text { Conductivity, (K) } \\
\mathrm{Js}^{-1} \mathrm{~m}^{-1} \mathrm{k}^{-1}\end{array}$ & $\begin{array}{c}\text { Thermal } \\
\text { diffusivity, ( } \alpha) \\
\mathrm{K} / \rho c \mathrm{~m}^{2} \mathrm{~s}^{-1}\end{array}$ \\
\hline Basalt & 2150 & 0.840 & $1.7-2.00$ & $9.41307 \mathrm{E}-07$
\end{tabular}

Foam board insulation $1.5^{\prime \prime}(3.75 \mathrm{~cm})$ thick was used to insulate the sides, bottom and back side of the drying chamber, collector and storage unit. black polyethylene film was attached to the bottom insulation, where it served as the absorber material. Transparent polycarbonate with a $90 \%$ transmittance of near infrared and visible wavelengths was used as the glazing material for the drying chamber cover and was responsible for filtering UV radiation, which may cause degradation of vitamins, color and flavor in tomatoes. The cover of the collector and storage unit also used the polycarbonate glazing material. The polycarbonate sheets 
were fixed to the dryer frame with industrial strength Velcro and can be easily removed for maintenance purposes.

\section{Raw materials and pre-drying treatment.}

Ripe tomatoes (Roma variety) were obtained from Agricultural Experimental Station, King Faisal University, and hand harvested at peak maturity. Tomatoes were sorted visually for colour (bright red), firmness, size and physical damage absence to remove defects, washed and then cut into halves, $5 \mathrm{~mm}$ thick slices and quarters with a clean knife. Cute tomatoes were dipped in $2 \%$ sodium meta-bisulfite solution for $2 \mathrm{~min}$ (Hasturk et al., 2011). The average initial moisture content of the tomatoes samples were determined by drying representative samples in a conventional oven at $105^{\circ} \mathrm{C}$ for 8-10 h (AOAC, 1995). The mean values of surface area, projected area, and mass of tomatoes pieces were measured and their values are given in table (2) as follow:

Table 2. The mean values mass, surface area and exposed area of fresh tomatoes pieces.

\begin{tabular}{lccc}
\hline & Halves & Discs & Quarters \\
\hline Mass $(\mathrm{g})$ & 53.53 & 9.54 & 26.37 \\
Surface Area $\left(\mathrm{mm}^{2}\right)$ & 5889.95 & 2802.6 & 3693.46 \\
Exposed Area $\left(\mathrm{mm}^{2}\right)$ & 1963.44 & 1194.53 & 1958.55 \\
S.A / M $\left(\mathrm{mm}^{2} / \mathrm{g}\right)$ & 110.09 & 295.01 & 140.43 \\
E.A / M $\left(\mathrm{mm}^{2} / \mathrm{g}\right)$ & 36.69 & 125.7 & 74.46 \\
\hline
\end{tabular}

\section{Measurments}

\section{- Solar radiation}

Solar radiation intensity was measured by a silicon pyranometer sensor (accuracy: Typically within $\pm 10 \mathrm{w} / \mathrm{m}^{2}$ ). The sensors were read at regular intervals by using a data logger and entered into a spreadsheet for analysis.

\section{- Air temperature and relative humidity}

During the drying process air temperature $\left({ }^{\circ} \mathrm{C}\right)$ and relative humidity $\%$ were continuously recorded at required points using the thermocouples sensors (Temp accuracy: $\pm 0.21{ }^{\circ} \mathrm{C}$ and $\mathrm{RH}$ accuracy: $\pm 2.5 \%$ ) at regular intervals $(60 \mathrm{~min})$ for all drying experiments. Temperature and relative 
humidity readings at a certain time intervals (60 min) was recorded using a data logging system and basic computer program.

\section{- Air velocity}

Air velocity in the stack was measured with a handheld anemometer during drying experiments.. The air velocity sensor was placed at the center axis of the dryer parts to estimate and compare the enhanced dryer and normal dryer air flow rates.

\section{- Moisture content}

The initial and final moisture content of the product was determined by using a standard laboratory oven method according to AOAC (1990). Time dependent moisture content of the samples was calculated from the sample weight and dry basis weight. Weight loss data allowed the moisture content to be calculated as follows:

$$
\text { M.C. }(t)=m_{w} / D_{M} \text {. }
$$

Where: $m_{w}=$ mass of the water in the sample at $(\mathrm{t})$

$D_{M}=$ mass of dry matter

\section{- Rehydration ratio}

Rehydration ratio was measured as the total mass of re-hydrated tomatoes per unit weight of dry mater.

\section{- Surface and exposed area}

Surface area was measured by wrapping aluminum foil around the piece of tomatoes and then measured using planemeter. While, exposed area was defined as the area projected to the sun.

\section{Experimental Procedures}

Experiments were performed during September through October 2013. Tomatoes were cute and treated as mentioned above. Three samples were picked randomly from the pre-treated tomatoes to determine the initial moisture content (92.24\%, w.b.). The pre-treated tomatoes were spread (single layer) on the mesh trays of the two dryers ( enhanced and normal dryer ) with a near uniform distribution density. The loading density of the drying tray was about $5.8 \mathrm{~kg} / \mathrm{m}^{2}$. The loaded trays were then placed very quickly in the drying chambers of the two dryers. Drying starts at $8.00 \mathrm{AM}$ and continuously during day and night. Drying data were monitored using labelled samples, which were individually weighed and 
positioned at the center and the two sides of each tray. The weights of the labelled samples were recorded every 1 hour throughout the drying test. To be sure about the uniform drying, which is necessary to achieve a consistent product, the tray locations were switched every hour during the drying process.

The drying test was terminated when the decrease in the weight of the samples had almost ceased. The dried samples were used to determine the final moisture content and quality properties.

Measurements of solar radiation, temperature, humidity, air speed at different points inside the drying system and tomato weight loss were recorded during the drying experiments and were used to compare the effectiveness of the two dryers. In the Drying system with storage unit, drying chamber was attached to storage unit by flexible duct $(20 \mathrm{~cm}$ diam.) at night only and attached to solar collector during day hours (8 A.M. to 6 P.M.). The dryers was tested under both day and night.

-Thermal performance of solar collector. Thermal performance of solar collector was evaluated. Quantity of heat which is converted by the absorber to the flowing air was calculated by the following equation:

$$
\mathrm{Q}_{\text {con }}=\mathrm{m} \cdot \mathrm{Cp} \cdot\left(\mathrm{T}_{\mathrm{o}}-\mathrm{T}_{\mathrm{i}}\right) / \mathrm{A}_{\mathrm{c}}
$$

Where: $\mathrm{Q}_{\mathrm{con}}=$ converted heat $\left(\mathrm{W} / \mathrm{m}^{2}\right)$

$\mathrm{Cp}=$ specific heat of air $\left(\mathrm{J} / \mathrm{kg} \cdot{ }^{\circ} \mathrm{C}\right)$

$\mathrm{m}=$ mass flow rate of air $(\mathrm{kg} / \mathrm{s})$

$\mathrm{T}_{\mathrm{o}}=$ outlet air temperature $\left({ }^{\circ} \mathrm{c}\right)$

$\mathrm{T}_{\mathrm{i}}=$ inlet air temperature $\left({ }^{\circ} \mathrm{c}\right)$

$\mathrm{A}_{\mathrm{c}}=$ absorbent area $\left(\mathrm{m}^{2}\right)$

The hourly efficiency of the collector was calculated by the following equation:

$$
\eta=\mathrm{m} \cdot \mathrm{Cp} \cdot \Delta \mathrm{T} /\left(\mathrm{I} \cdot \mathrm{A}_{\mathrm{c}}\right) .
$$

Where: $\mathrm{I}=$ solar intensity $\quad\left(\mathrm{W} / \mathrm{m}^{2}\right)$

$$
\text { Effectivness }=\left(\mathrm{T}_{\mathrm{o}}-\mathrm{T}_{\mathrm{i}}\right) /\left(\mathrm{T}_{\max }-\mathrm{T}_{\mathrm{i}}\right)
$$

Where: $\mathrm{T}_{\max }=$ The maximum temperature of the absorbing surface.

- Thermal performance of storage unit: Thermal performance of storage unit was studied through the following; 
All experiments carried out with closed units during daylight and opened in the night.In sensible heat storage (SHS), thermal energy is stored by raising the temperature of a solid or liquid, utilizing the heat capacity and change in temperature of the material during the process of charging and discharging. The amount of heat stored( $Q_{s}$ )depends on the specific heat of the medium, the temperature change and the amount of storage material (Bal et al., 2010). The quantity of heat recovered $\left(Q_{r}\right)$ by the storage units was calculated that all heat stored during daylight is recovered during the night $\mathrm{Q}_{\mathrm{r}}=\mathrm{Q}_{\mathrm{s}}$ by using the following equation:-

$$
Q_{\mathrm{s}}=\mathrm{m}^{*} \mathrm{C}_{\mathrm{P}} *\left(\mathrm{~T}_{\mathrm{f}}-\mathrm{T}_{\mathrm{i}}\right)
$$

Where: $Q_{s}=$ quantity of heat stored

$$
\begin{aligned}
& \text { (W.hr) } \\
& \mathrm{m} \text { = mass of storage material } \\
& \mathrm{C}_{\mathrm{p}}=\text { specific heat of storage material } \\
& \left(\mathrm{J} / \mathrm{kg} \cdot{ }^{\circ} \mathrm{C}\right) \\
& \mathrm{T}_{\mathrm{f}}=\text { average final temperature of storage material } \\
& \mathrm{T}_{\mathrm{i}}=\text { the initial temperature of storage material (after time } \mathrm{t} \text { of } \\
& \text { exposure to solar radiation }
\end{aligned}
$$

Available energy from solar radiation stored in the storage units thus the thermal efficiency was considered storage efficiency of storage $\operatorname{units}\left(\eta_{s}\right)$ :- is determined as follows:

$$
\eta_{s}=\frac{Q_{s}}{I A t} \times 100
$$

Where: $Q_{s}=$ quantity of heat store by storage unit

(W.hr)

$\mathrm{I}=$ average solar intensity on storage surface over daylight $\left(\mathrm{W} / \mathrm{m}^{2}\right)$

$$
\begin{aligned}
& \mathrm{A}=\text { surface area of storage unit } \\
& \left(\mathrm{m}^{2}\right) \\
& \mathrm{t}=\text { time of exposure radiation } \\
& \text { (second) }
\end{aligned}
$$

\section{-Drying modelling:}

The Newtonian or exponential model successfully describes the drying of kinetics of some porous materials such as food material(Skansi and 
Tomas, 1995; Sander, Tomas and Skansi, 1998Tomas and Skansi, 1996) The drying curves were fitted with the exponential or Newtonian equation:

$$
\frac{M-M e}{M o-M e}=e^{-k t}
$$

The values of the equilibrium moisture content are relatively small compared to instantaneous moisture content and initial moisture content the moisture ratio can be simplified to $\mathrm{M}_{t} / \mathrm{M}_{o}$.(Doymaz and pala, 2002 and Workneh, et al., 2011). $\mathrm{M} t$ is moisture content at any time (t), $\mathrm{M}_{o}$ is initial moisture content, expressed a dry basis.

The drying curve for each experiment was obtained by plotting the dimensionless moisture ratio of the sample 'vs' the drying time. A regression of the moisture falling reduction $(\ln (\mathrm{M} / \mathrm{Mo}))$ with drying time was conducted using exponential equation to obtain expected values of drying constant $(\mathrm{k})$.

\section{Sensory evaluation}

The sensory qualities of different tomatoes were carried out in Sensory Evaluation Lab., Food and Nutrition Sciences Department, Faculty of Agricultural and Food Sciences, King Faisal University. The sensory evaluation were analyzed in terms of its appearance, color, flavor, texture and taste. A ten number panel, all of whom were experienced in the sensory evaluation of food. A ten point scale was used where $10=$ excellent and 1 = extremely poor. Accuracy and precision were statistically analyzed.

\section{Statistical analysis}

The data analysis of this experiment was carried out by using the statistical analysis system. Measured data were analyzed by ANOVA. Least significance Difference test was used to determine difference between means. Significance was assumed at $(p \leq 0.05)$.

\section{RESULTS AND DISCUSSIONS}

\section{Thermal performance of solar collector:}

Table 4 contains data of inlet and outlet air temperatures, maximum and average temperature of absorber, solar insolation on the collector surface, heat converted by the absorber to the flowing air, solar collector efficiency and effectiveness at different solar time starting 8.00 AM to 6.00 PM. 


\section{Table 4. Thermal performance parameters of solar collector.}

[September / 27, 28, 29/2013]

\begin{tabular}{|c|c|c|c|c|c|c|c|c|c|c|}
\hline \multirow{2}{*}{$\begin{array}{l}\text { Solar } \\
\text { time } \\
\text { (hour) }\end{array}$} & \multirow{2}{*}{$\begin{array}{l}\mathrm{T}_{\mathrm{amb}} \\
\left({ }^{\circ \mathrm{C}}\right)\end{array}$} & \multirow{2}{*}{$\begin{array}{c}\mathrm{T}_{\mathrm{o}} \\
\left({ }^{\circ} \mathrm{C}\right)\end{array}$} & \multirow{2}{*}{$\begin{array}{l}\Delta \mathrm{T} \\
\left({ }^{\circ} \mathrm{C}\right)\end{array}$} & \multirow{2}{*}{$\begin{array}{l}\Delta \mathrm{T} / \mathrm{m}^{2} \\
{ }^{\mathrm{C}} \mathrm{C} / \mathrm{m} 2\end{array}$} & \multicolumn{2}{|c|}{$\begin{array}{l}\text { Absorber } \\
\left.\text { temp. ( }{ }^{\circ} \mathrm{C}\right)\end{array}$} & \multirow{2}{*}{$\begin{array}{c}\text { Solar } \\
\text { irradiation } \\
\left(\mathrm{w} / \mathrm{m}^{2}\right)\end{array}$} & \multirow{2}{*}{$\begin{array}{c}\text { Heat } \\
\text { converted } \\
\left(\mathrm{W} / \mathrm{m}^{2}\right)\end{array}$} & \multirow{2}{*}{$\begin{array}{c}\text { Efficiency } \\
(\%)\end{array}$} & \multirow[t]{2}{*}{$\begin{array}{c}\text { Effectiveness } \\
(\%)\end{array}$} \\
\hline & & & & & Mean & Max. & & & & \\
\hline 8 & 23.25 & 24.60 & 1.36 & 1.14 & 25.95 & 27.00 & 223.1 & \begin{tabular}{|l|}
104.96 \\
\end{tabular} & 47.0 & 36.26 \\
\hline 9 & 29.69 & 33.07 & 3.38 & 3.21 & 36.32 & 37.50 & 438.1 & 247.75 & & 43.27 \\
\hline 10 & 32.87 & .11 & 6.24 & 5.94 & 46.50 & 48.0 .2 & 724.9 & 458.6 & & 41.18 \\
\hline 11 & 35.18 & 44.98 & 9.80 & 9.33 & 55.36 & 58.6 & 982.5 & 720.11 & & 41 \\
\hline 12 & 36.28 & 47.28 & 11.0 & 10.47 & 58.10 & 61.20 & 1078.7 & 808.57 & 74.96 & 44.14 \\
\hline 13 & 38.00 & 50.60 & 12.60 & 12.00 & 63.02 & 64.00 & 1187.7 & 926.19 & 77.98 & 48.46 \\
\hline 14 & 37.80 & 47.60 & 9.80 & 9.33 & 61.2 & 63.32 & 978.6 & 720.37 & 73. & 38.4 \\
\hline 15 & 37.40 & 46.40 & 9.00 & 8.57 & 58.6 & 60.23 & 975.1 & 661.56 & & 39.4 \\
\hline 16 & 36.22 & 43.57 & 7.35 & 7.00 & 54.6 & 55.60 & 837.6 & 540.27 & 64.51 & 37.9 \\
\hline 17 & 35.52 & 40.44 & 5.92 & 5.63 & 48.21 & 51.65 & 716.9 & 435.16 & 60.70 & 36.7 \\
\hline 18 & 29.9 & 32.85 & 2.95 & 2.80 & 40.22 & 41.10 & 406.9 & 216.84 & 53.29 & 26.3 \\
\hline Mean & 30.39 & 37.68 & 7.23 & 6.85 & 42.22 & 51.64 & 777.28 & 530.94 & 64.82 & 35.63 \\
\hline
\end{tabular}

The rise in air temperature between inlet and outlet $(\Delta \mathrm{T})$ starts small in the morning and gradually increases until it reached maximum at one P.M. then decreased gradually until sunset. Coincidentally, the maximum and average absorber temperature, the converted heat, the thermal efficiency and effectiveness followed the same trend. The performance of solar collector investigated was very satisfactory.

\section{Thermal performance of storage unit :}

The solar storage unit was closed during the day hours (8 AM - $6 \mathrm{PM})$ then connected to the drying chamber during night hours with 0.075 $\mathrm{m}^{3} / \mathrm{sec}$ air flow rate to provide a source for energy to continue drying during the night hours. As show in table 5, the hourly useful energy by the storage unit increased gradually and reaches the maximum values after noon, then decreased gradually until sunset. This due to the intensity of solar radiation became less than that adds heat to the storage unit as well as heat lost through unit. The daily stored energy per mas unit was $34.08 \mathrm{~kJ} / \mathrm{kg}$. The mean hourly storage efficiency was about $48.91 \%$. The maximum difference between ambient and storage materials temperature was obtained at sunset.

\section{Dryer performance evaluation:}

Results of preliminary experiments on both dryers were used to operate the dryers under the optimum operating conditions. Satisfactory drying was achieved but the drying rate during night hours was very slow in normal dryer, thus use of storage unit was investigated to improve the 
drying rate after sundown. In assessing the solar dryers performance, drying air temperature and drying rates were evaluated.

Fig.2 represents the ambient air temperature, ambient air relative humidity and drying air temperature inside the dryers (average values at different point) during drying trial carried out on October / 4, 5, 6 / 2013. The ambient temperature remains much lower than that in either the mixed dryers without storage unit (normal dryer)and with storage unit (enhanced) during the day hours. Ambient air temperature varied between $21.98^{\circ} \mathrm{C}$ (at night) and 42.07

Table 5: Thermal performance parameters of solar storage unit.

[September / 27, 28, 29/2013]

\begin{tabular}{|c|c|c|c|c|c|}
\hline $\begin{array}{l}\text { Solar time } \\
\text { (hour) }\end{array}$ & $\begin{array}{c}\mathrm{T}_{\mathrm{i}} \\
\left({ }^{\left({ }^{2} \mathrm{C}\right)}\right.\end{array}$ & $\begin{array}{l}\mathrm{T}_{\mathrm{f}} \\
\left({ }^{\circ} \mathrm{C}\right)\end{array}$ & $\begin{array}{l}\Delta \mathrm{T}_{\mathrm{s}} \\
\left({ }^{\circ} \mathrm{C}\right)\end{array}$ & $\begin{array}{c}\text { Qs } \\
\text { (W.h) }\end{array}$ & $\begin{array}{c}\text { Storage } \\
\text { Efficiency }(\%) \\
\end{array}$ \\
\hline $8-9$ & 26.20 & 27.71 & 1.51 & 159.07 & 45.8 \\
\hline $9-10$ & 27.7 & 32.2 & 4.50 & 474.07 & 62.33 \\
\hline $10-11$ & 32.2 & 37.5 & 5.30 & 558.35 & 69.33 \\
\hline $11-12$ & 37.5 & 44.15 & 6.65 & 700.57 & 72.74 \\
\hline $12-13$ & 44.15 & 51.15 & 7.00 & 737.45 & 64.00 \\
\hline $13-14$ & 51.15 & 56.05 & 4.90 & 516.2 & 49.38 \\
\hline $14-15$ & 56.05 & 60.75 & 4.70 & 495.14 & 48.27 \\
\hline $15-16$ & 60.75 & 63.85 & 3.1 & 326.58 & 34.31 \\
\hline $16-17$ & 63.85 & 65.65 & 1.8 & 189.63 & 23.29 \\
\hline $17-18$ & 65.65 & 66.75 & 1.1 & 115.88 & 19.65 \\
\hline $18-19$ & 66.75 & 60.40 & -6.35 & -668.9 & \\
\hline $19-20$ & 60.40 & 54.35 & -6.05 & -637.36 & \\
\hline $20-21$ & 56.35 & 53.35 & -3.00 & -316.05 & \\
\hline $21-22$ & 53.35 & 50.66 & -2.69 & -283.39 & \\
\hline $22-23$ & 50.66 & 48.32 & -2.34 & 246.52 & \\
\hline $23-24$ & 48.32 & 46.03 & -2.29 & -241.25 & \\
\hline $24-1$ & 46.03 & 43.91 & -2.12 & -223.34 & \\
\hline $1-2$ & 43.91 & 41.50 & -2.41 & -253.89 & \\
\hline $2-3$ & 41.50 & 39.00 & -2.50 & -263.37 & \\
\hline $3-4$ & 39.00 & 37.20 & -1.8 & -189.63 & \\
\hline $4-5$ & 37.20 & 33.71 & -3.49 & -367.67 & \\
\hline $5-6$ & 33.71 & 29.65 & -4.06 & -427.72 & \\
\hline $6-7$ & 29.65 & 25.68 & -3.97 & -418.23 & \\
\hline $7-8$ & 25.68 & 26.20 & 0.52 & 54.78 & \\
\hline
\end{tabular}




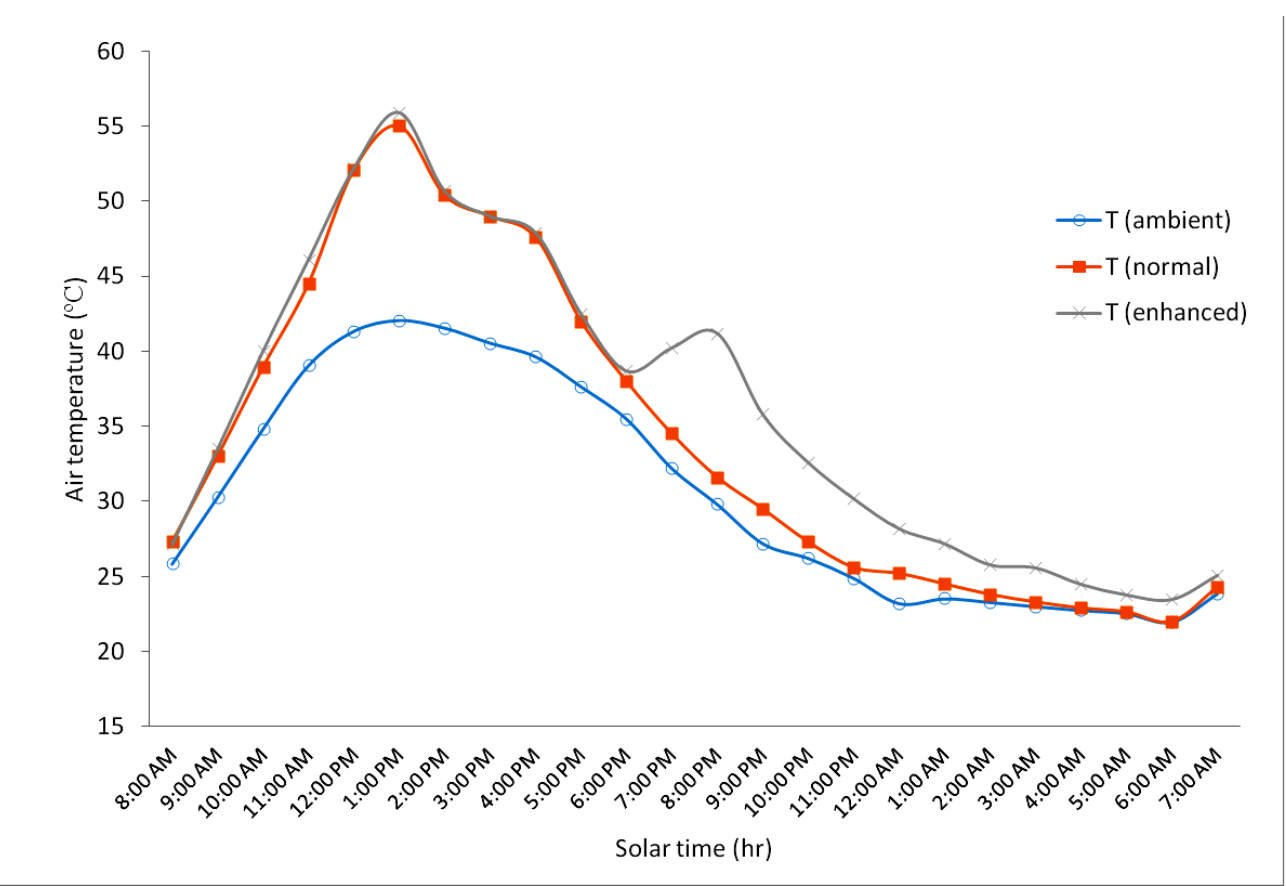

Fig. 2 Air temperature VS solar time during experimental drying of tomatoes.

${ }^{\circ} \mathrm{C}$ (at one P.M.) giving average $30.04{ }^{\circ} \mathrm{C}$. The drying air temperature inside enhanced dryer was very close to that in normal dryer during day hours, while during the night hours, the air temperature inside enhanced dryer averaged $5{ }^{\circ} \mathrm{C}$ above that inside normal dryer. Drying air temperature was consistently highest inside enhanced dryer averaged $6.75{ }^{\circ} \mathrm{C}$ above ambient air temperature (day and night). A peak of 12.83 above ambient air temperature was recorded at noon for both dryers.

Fig. 3 shows changes in the relative humidity versus solar time for the dryers and ambient air. Relative humidity in the enhanced dryer with storage unit is consistently lower than both the normal dryer and the ambient air relative humidity values. The drying air relative humidity in the dryer with storage unit averaged $5.74 \%$ under in the normal dryer during night hours while during day hours was approximately the same. 


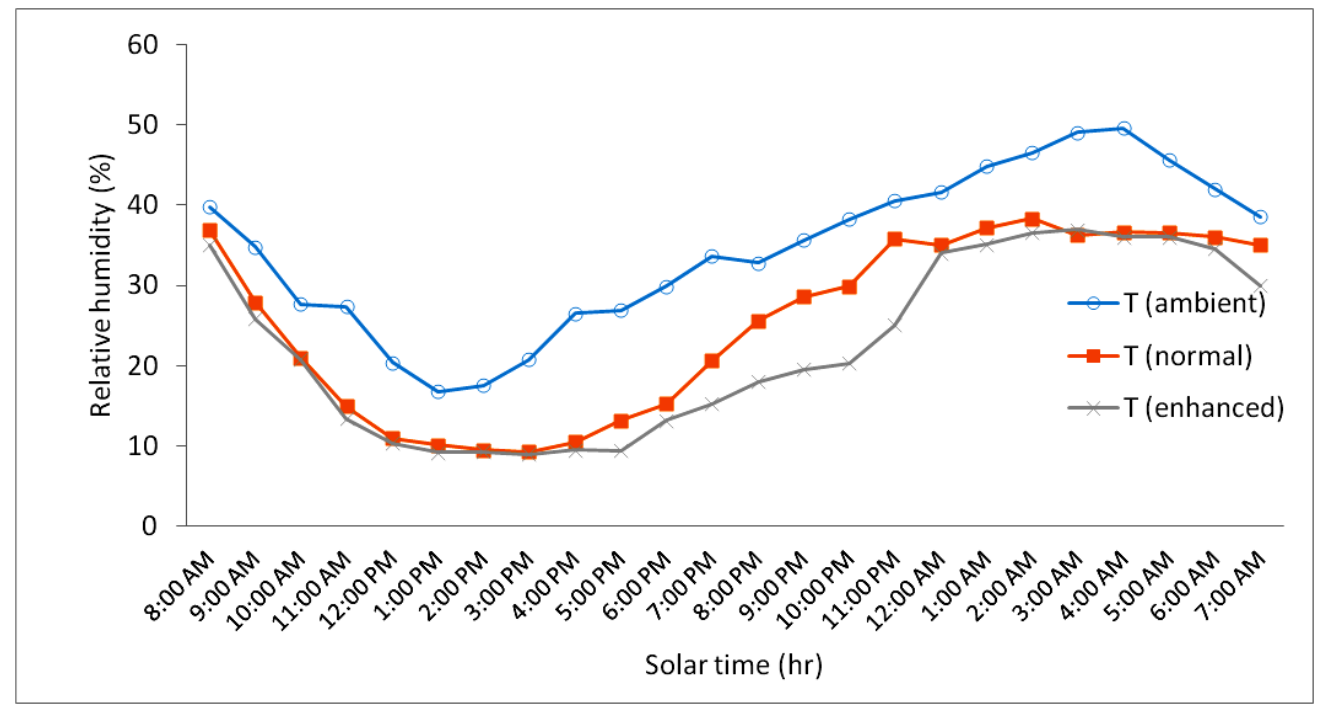

Fig. 3 Air relative humidity VS solar time during experimental drying of tomatoes.

The temperature always relatively low at the beginning and the end of the day reached to maximum value afternoon and then started to decrease again and much lower during night hours. The relative humidity has a reverse trend to that of the temperature.

Linear regression analysis between both ambient and drying air temperatures and solar insolation are illustrated in Fig. 4, the regression equations were:

$$
\begin{array}{lll}
\mathrm{T}_{\text {amb. }}=0.01251+24.169 & \mathrm{R}^{2}=0.9168 \\
\mathrm{~T}_{\text {dryer }}=0.02651+22.873 & \mathrm{R}^{2}=0.9143
\end{array}
$$

Tomatoes in halves were dried in preliminary experiments by two dryers ,but moisture evaporation into the warm air in the drying chamber resulted in water saturation resulting in a substantial quantity of condensed droplets of water. These condensed water droplets were visible in the glass facing inside the dryer. The droplets drop on the product surface particularly when there was insufficient air flow rate at sunset and early morning. The slow drying and high humidity in the drying chamber made the tomatoes halves relatively deteriorate before they dried. Molding and deterioration was evident in both dryers and was manifested by a very dark colored product especially in mixed dryer without storage unit. Thus, drying of tomatoes halves is not recommended. 


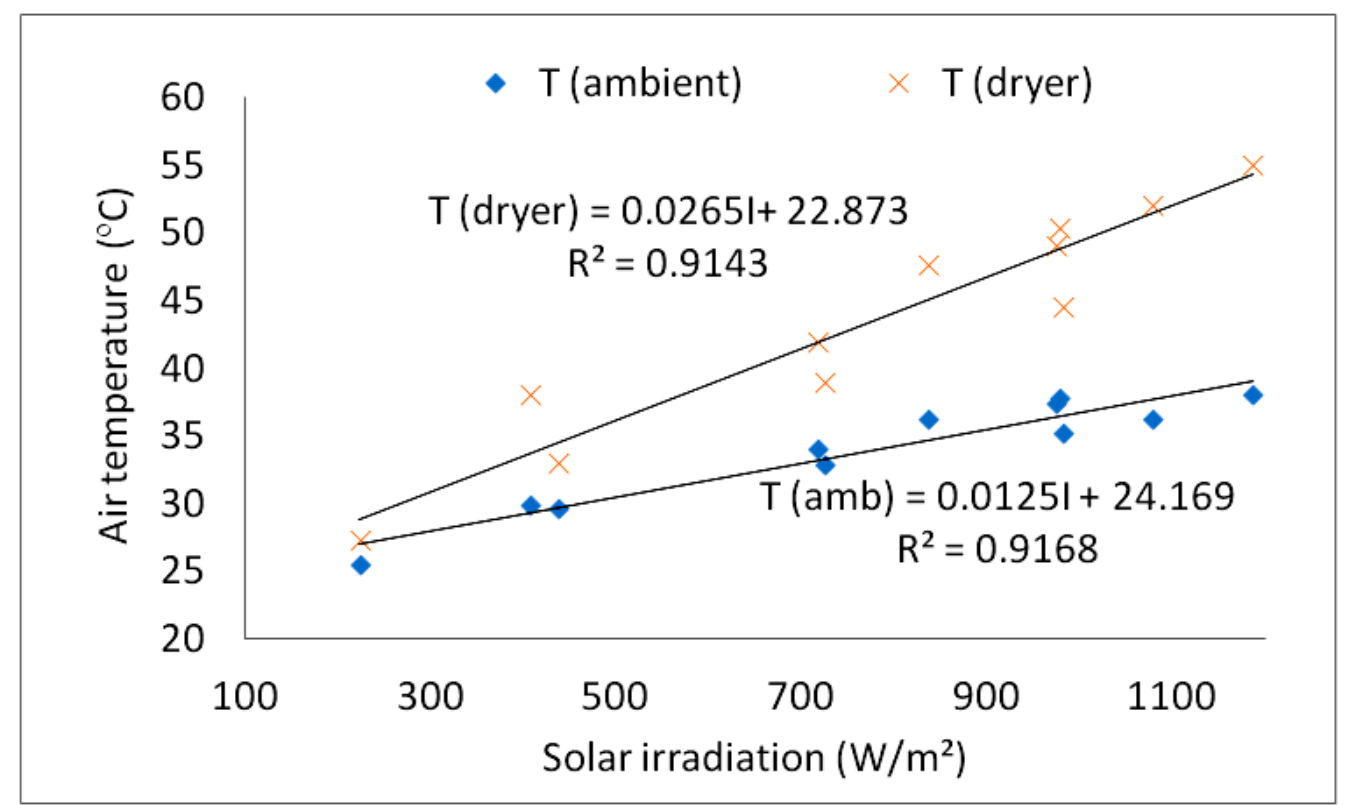

Fig. 4 The relation between solar irradiation and air temperatures (ambient and average value inside the dryers)

Data given in table 6 show moisture content (d.b.) vs drying time for different shapes of tomatoes (quarters and discs) dried by two dryers. Also, Fig. 5 shows the drying curves for the experimental drying. The moisture content represented mean values of samples from different trays in the dryer. The mixed dryer with storage unit had a much higher rate of moisture reduction than the other dryer at night. The horizontal segment in the drying curve which was manifested between 12 and 24 hour of drying in normal dryer presented night hours where approximately no drying occurred. In fact, under certain situations re-absorption of moisture by the product at late night hours in the control dryer. The required drying time to reach final moisture content of 12.11 and $11.73 \%$ (d.b.) for quarters and discs were 54and 50 hours respectively in the normal dryer, while the required drying time to reach final moisture contents of 11.73 and $11.29 \%$ (d.b.) for quarter and discs were 36 and 32 hours respectively in enhanced dryer. It can be seen also, for the first 6 hours of drying the trend in moisture losses in the two dryers are similar curves show constant drying rate during this period. This occurs as there is considerable free surface moisture in the product. However, as drying 
progressed, moisture movement from within the product to the surface made moisture removal increasingly difficult and moisture loss slowed down considerably. At any time in the drying curves, the moisture contents for the discs was less than those for quarters little bit.

Table 6: Moisture content (w.b.) VS drying time for tomatoes pieces dried by normal and enhanced dryers.

\begin{tabular}{|c|c|c|c|c|c|}
\hline \multirow{2}{*}{$\begin{array}{l}\text { Solar time } \\
\text { (hr) }\end{array}$} & \multirow{2}{*}{$\begin{array}{l}\text { Drying } \\
\text { time (hr) }\end{array}$} & \multicolumn{2}{|c|}{ M.C.(w.b.) Quarters \% } & \multicolumn{2}{|c|}{ M.C. (w.b.) Discs \% } \\
\hline & & $\begin{array}{c}\text { Normal } \\
\text { dryer }\end{array}$ & $\begin{array}{c}\text { Enhanced } \\
\text { dryer }\end{array}$ & $\begin{array}{l}\text { Normal } \\
\text { dryer }\end{array}$ & $\begin{array}{c}\text { Enhanced } \\
\text { dryer }\end{array}$ \\
\hline 8 & 0 & 92.24 & 92.24 & 92.24 & 92.24 \\
\hline 10 & 2 & 85.6 & 85.6 & 84.7 & 84.6 \\
\hline 12 & 4 & 75.2 & 75.1 & 73.6 & 73.4 \\
\hline 14 & 6 & 65.9 & 65.8 & 64.1 & 63.9 \\
\hline 16 & 8 & 55.4 & 55 & 53.4 & 53.2 \\
\hline 18 & 10 & 48.7 & 48.5 & 45.1 & 44.9 \\
\hline 20 & 12 & 46.2 & 43.2 & 44.1 & 40.4 \\
\hline 22 & 14 & 45.9 & 38.2 & 43.8 & 35.4 \\
\hline 24 & 16 & 45.5 & 34.8 & 43.5 & 31.6 \\
\hline 2 & 18 & 45.3 & 31.8 & 43.2 & 27.8 \\
\hline 4 & 20 & 45.5 & 29.8 & 43.1 & 25.6 \\
\hline 6 & 22 & 45.3 & 24.3 & 43.2 & 20 \\
\hline 8 & 24 & 42.8 & 20.1 & 39.9 & 16.1 \\
\hline 10 & 26 & 36.7 & 16.9 & 33.1 & 13.2 \\
\hline 12 & 28 & 31 & 14.5 & 28.1 & 11.3 \\
\hline 14 & 30 & 26.1 & 12.5 & 23.6 & 10.8 \\
\hline 16 & 32 & 22.8 & 11.5 & 19.4 & 10.15 \\
\hline 18 & 34 & 19.7 & 10.8 & 16.3 & \\
\hline 20 & 36 & 18 & 10.5 & 14.9 & \\
\hline 22 & 38 & 17.5 & & 13.8 & \\
\hline 24 & 40 & 16.2 & & 12.9 & \\
\hline 2 & 42 & 16 & & 12.8 & \\
\hline 4 & 44 & 16 & & 12.8 & \\
\hline 6 & 46 & 16.1 & & 12.9 & \\
\hline 8 & 48 & 14.5 & & 11 & \\
\hline 10 & 50 & 12.9 & & 10.5 & \\
\hline 12 & 52 & 11.2 & & & \\
\hline 14 & 54 & 10.8 & & & \\
\hline
\end{tabular}



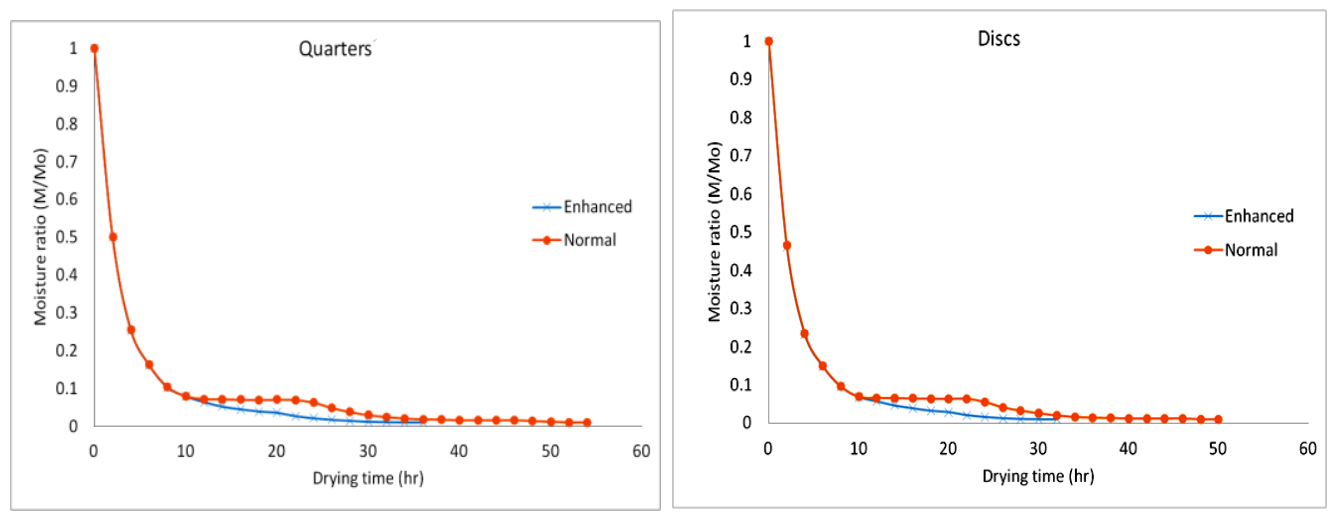

Fig. 5: Moisture ratio VS drying time for tomatoes by normal mixed solar dryer and enhanced solar dryer.

The following values for drying constant $(\mathrm{k})$ were found 0.284 and 0.312 for quarters and discs respectively in the enhanced dryer, while drying constant $(\mathrm{k})$ were 0.212 and 0.197 for quarters and discs respectively in the normal mixed dryer. The relatively low fit of falling rate moisture change expressed as an exponential function for the normal mixed dryer without storage unit $\left(\mathrm{R}^{2}=0.782\right)$ was due to a deviation of experimental data from the fitted equation during the night hours. These results explain the effectiveness of increased drying air temperature on the improvement the drying rate. The regression analysis revealed significant relationship between drying rate constant and air temperature. The regression equation was

$$
\mathrm{K}=-0.4195+0.01798 \mathrm{~T} \quad \mathrm{R}^{2}=0.9451
$$

The overall drying rates $(\Delta \mathrm{M}(\mathrm{d}$.b. $) / \mathrm{hr})$ were 0.326 and 0.367 for quarters and discs in enhanced dryer, while were 0.217 and 0.235 in normal dryer respectively.

\section{Quality properties:}

The quality of dried tomatoes was measured by testing final moisture content, rehydration ratio and sensory properties (appearance, color, flavor and taste). The general results of final moisture content of the dried tomatoes quarters and discs did not show significant different. The enhanced dryer produced dried tomatoes with the highest rehydration ratio. This may be explained by the shorter drying time which opened pores within the dried tomatoes to facilitate water penetration during rehydration. No significant differences were noticed among the quarters and discs in both dryers, this may be due to moisture content of them is 
relatively close. Sensory Properties of tomatoes quarters were very closed to tomatoes discs. Dried tomatoes by enhanced dryer gave a higher score for appearance, color and taste compared to the dried tomatoes to in normal dryer. It can be concluded that dried tomatoes dried by enhanced dryer had the higher overall acceptability than tomatoes dried by normal dryer.

\section{CONCLUSSION}

This study reveals the effect of adding solar storage unit to a mixed-mode solar dryer to allow continuous drying after sundown. The conclusion was as follows:

1- The measured air temperature inside the drying chamber of mixed dryer with storage unit was noticeably higher than that of a normal mixed-mode dryer of identical design at night hours and air relative humidity had a reverse trend

2- Storage unit attached to drying chamber after sundown ensures a faster drying rate by increasing drying rates 33.3 and $36 \%$ for tomatoes quarters and discs respectively and it therefore reduce the chance of spoilage

3- The converted heat, consequently, the collector efficiency and storage efficiency increased gradually until afternoon, then started to decrease until sunset.

4- The required drying time to reach final moisture content of 12.11 and $11.73 \%$ (d.b.) for quarters and discs were 54 and 50 hours respectively in the normal, while the required drying time to reach final moisture contents of 11.73 and $11.29 \%$ (d.b.) for quarter and discs were 36 and 32 hours respectively in enhanced dryer

5- Newtonian or exponential model fitted very well the experimental data for the dryer with storage unit and can be further applied to predict the thin layer solar drying behavior of tomatoes.

6- Drying constant (K) was greatly affected by drying air temperature and ratio exposed surface area to product mass.

7- The overall drying rates (kg W/ kg D.M.h) were 0.326 and 0.367 for quarters and discs in enhanced dryer, while were 0.217 and 0.235 in normal dryer respectively.

8 - Drying of tomatoes discs and quarters by enhanced dryer revealed good color, taste and appearance, meanwhile tomatoes halves gave 
PROCESS ENGINEERING

unacceptable color. So, drying of halves is generally not recommended

\section{REFERENCES}

Abdellatif, S. M. (1985). "Solar energy collection, storage and utilization in protected cropping". Ph.D. Wye College, University of London, UK.

AOAC (1995). "Association of Official Analytical Chemists" $15^{\text {th }}$ d., Published by AOAC, 2200 Wilson Boulevard Arlington, Virginia 22201 U.S.A.

Bal, M.L.; S. Satya and S.N. Naik (2010). "Solar dryer with thermal energy storage systems for drying agricultural food products: A review". Renewable and Sustainable Energy Reviews, 14.; 22982314.

CAPMS. (2011). "Annual year book for general statistics. Central Agency for public Mobilization and Statistics of A.R.E"., Egypt.

Dincer, I. and S. Dost (1996). "A perspective on thermal energy storage systems for solar energy applications". International journal of energy research, vol. 20, 547-557.

Dincer, I. and A. M. Rosen (2010). "Thermal energy storage systems and applications", John Wiley \& Sons, Ltd. United Kingdom.

Doymaz, I. and M. Pala (2002). "The effects of dipping pretreatments on air-drying rates of the seedless grapes". Journal of Food Engineering, 52(4), 413-417.

Duffie, J. A. and W. R. Beckman (2006). "Solar Engineering for Thermal Processes". $3^{\text {rd }}$ Ed., pp. 907. John Wiley and Sons. New York: USA.

Gamea, G. R.; A. T. Taha and M. H. Keshek (2012). "Thermal performance of solar energy storage in some solid materials". Misr J. Ag. Eng. Vol. 29 (1):429 - 350.

Gustavsson. J.; C. Cederberg; U. Sonesson; R. V. Otterdijk and A. Meybeck (2011). "Global Food Losses and Food Waste". Food and Agricultural Organization.

Hasturk, F.; T. Aktas; H. Orak and P. Ulger (2011). "Influence of Pretreatment and different drying methods on color parameters and lycopene content of dried tomato". Bulgarian journal of Agricultural science, 17 (6): $867-883$. 
Johnson, R. W. (1992). "Analytical results for specific system Passive solar buildings". The MIT Pres, Cambridge, Massachusets, London.

Joshi, C.; M. Gewali and R. Bhandari (2004). "Performance of solar drying systems: a case study of Nepal". Inst. Eng. (India), (7): 53 85 .

Mohamed M. A., G. R. Gamea and M. H. Keshek (2010). "Drying characteristics of okra by different solar dryers". Misr J. Ag. Eng. Vol. 27 (1): $294-312$.

Simate, I. (2001). "Simulation of the mixed-mode natural-convection solar drying of maize". Drying Technology; 19 (6): 1137-55.

Vlachos, N.A.; T. D. Karapantsios; A. I. Balouktsis and D. Chassapis (2002) "Design and testing of a new solar tray dryer". Drying Technol; 20 (6): 1243-71.

Duffie, J. A. and W. R. Beckman (2006). "Solar engineering for thermal processes". $3^{\text {rd }}$ ed., pp. 907. John Wiley and Sons. New York: USA.

Mohamed, M. A.; G. R. Gamea and M. H. Keshek (2010). "Drying characteristics of okra by different solar dryers". Misr J. Ag. Eng. Vol. 27(1): $294-312$.

Ozturk, H. H. and A. Bascetincelik (2003). "Energy and energy efficiency of a packed bed heat storage unit for greenhouse heating". Biosyst Eng; 86 (2): 231 - 245.

Sander, A.; S. Tomas and D. Skansi (1998). The influence of air temperature on effective diffusion coefficient of moisture in the falling rate period. Drying Technology, 16 (7): 1487-1499.

Skansi, D. and S. Tomas (1995). Microwave drying kinetics of a clay plate. Ceramics International, 21, 207-211.

Somerton, H. W. (1992). "Thermal properties and temperature-related behavior of rock/fluid systems". Elsevier Publishing Company.

Tomas, S. and D. Skansi (1996). "Numerical interpretation of drying curve of food products". Journal of Chemical Engineering of Japan, 29 (2): 367-370.

Workneh, T. S.; V. Raghavan and Y. Gariepy (2011). "Microwave assisted hot air ventilation drying of tomato slices". International conference on food engineering biotechnology. Singapoor. IPCBEV, Vol. 9, 150-162. 


\section{تصميم وتقييم مجفف شمسي محسن مزود بخز العزب ان حرارى لتجفيف الطماطم

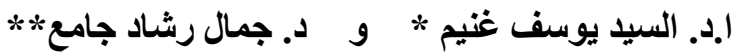

يتجه العالم باسره الآن في البحث عن مصادر جديدة للطاقة لتغطية احتياجاته المتز ايدة بازدياد

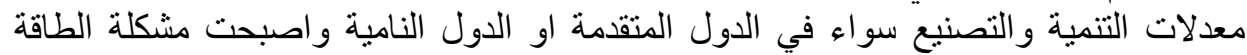

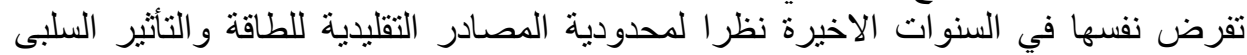

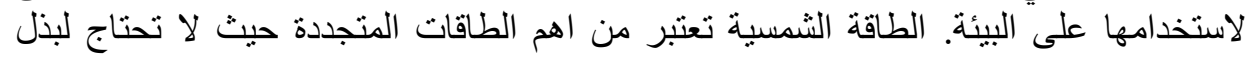

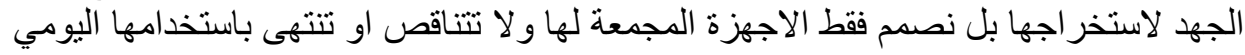

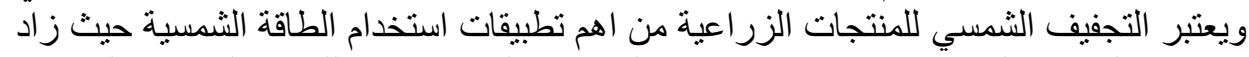

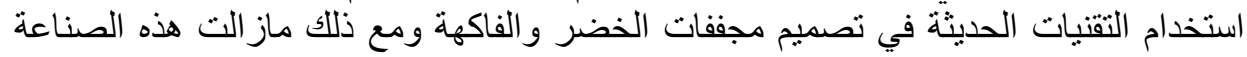

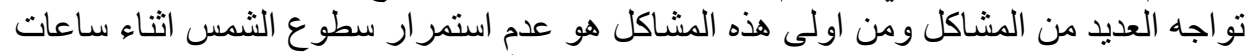

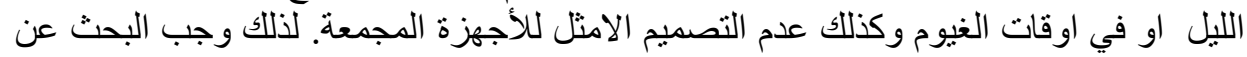

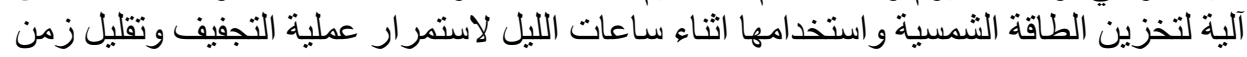

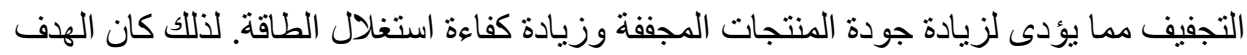

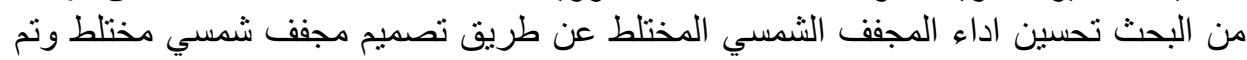

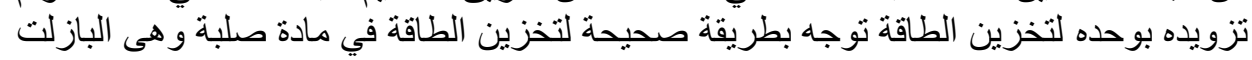

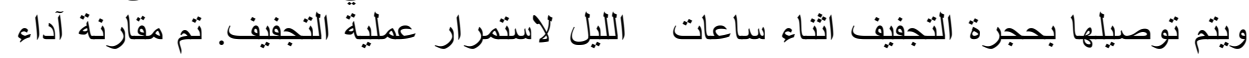

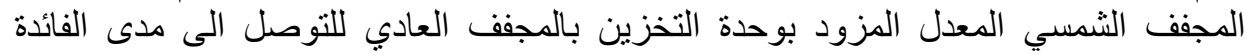

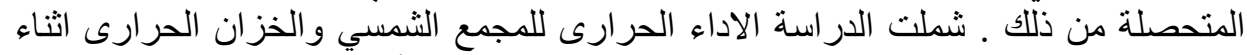

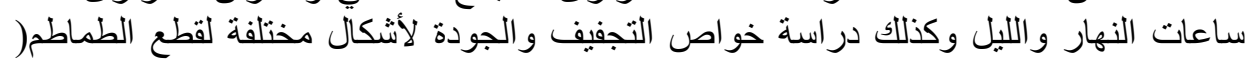

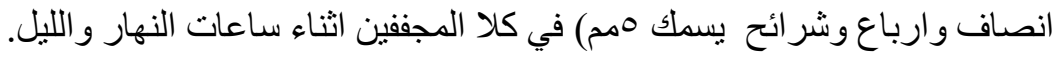
وون اهم النتائج المتحصل واعل عليها: ا - زادت درجة الحرارة داخل المجفف المحسن اثناء ساعات الليل عن المجفف العادي بقيمة

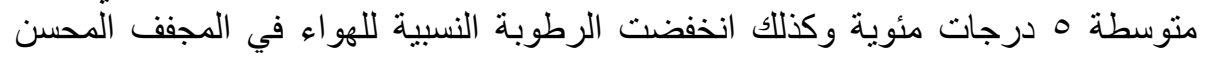

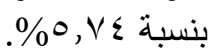

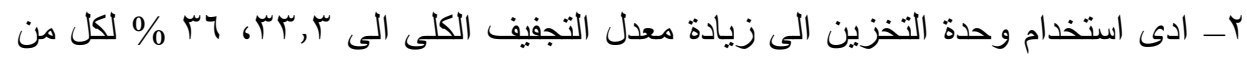

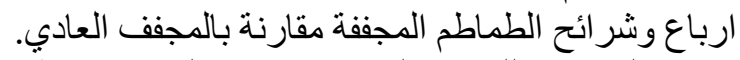

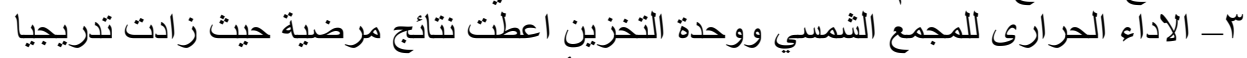

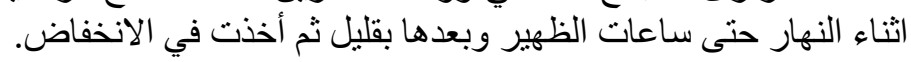

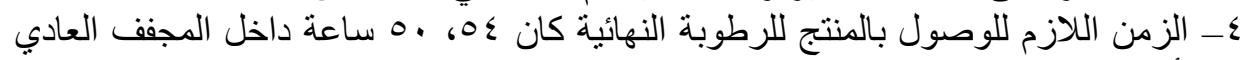

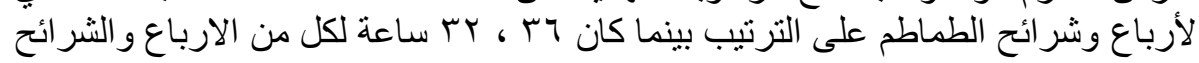

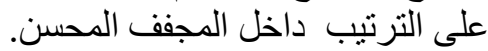

$$
\begin{aligned}
& \text { 0ـ يمكن وصف معدلات التجفيف داخل المجفف المعدل بو اسطة : }
\end{aligned}
$$

Newtonian or exponential model

7- خو اص الجودة لشـر ائح الطماطم والأربـاع داخل المجفف المحسن اعطت نتائج جيدة جدا

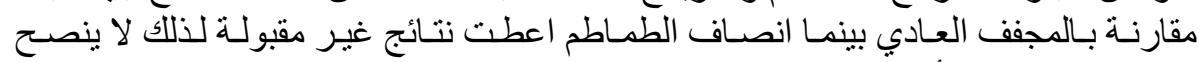

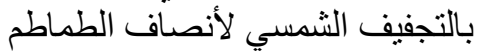

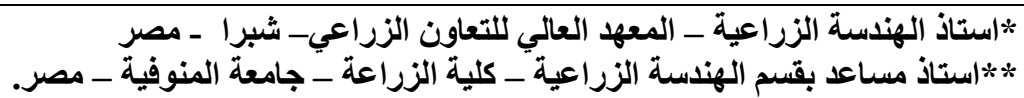

